\title{
Electron Microscopic Detection of Novel, Coiled Viruslike Particles Associated with Graft-Inoculation of Prunus Species
}

\author{
D. James and S. E. Godkin, Centre for Plant Health, Canadian Food Inspection Agency, 8801 East Saanich Road, \\ Sidney, B.C., Canada, V8L 1H3; F. R. Rickson, Oregon State University, Corvallis 97331-2902; D. A. Thompson, \\ Centre for Plant Health, Canadian Food Inspection Agency, 8801 East Saanich Road, Sidney, B.C., Canada, V8L \\ 1H3; K. C. Eastwell, Washington State University, IAREC, 24106 Bunn Road, Prosser 99350; and A. J. Hansen, \\ Agriculture and Agri-Food Canada, Pacific Agri-Food Research Centre, Summerland, B.C., Canada, V0H 1 Z0
}

\begin{abstract}
James, D., Godkin, S. E., Rickson, F. R., Thompson, D. A., Eastwell, K. C., and Hansen, A. J. 1999. Electron microscopic detection of novel, coiled viruslike particles associated with graftinoculation of Prunus species. Plant Dis. 83:949-953.

Coiled, viruslike particles (spirions) were detected by electron microscopic examination of crude extracts from flowers, leaves, and/or roots of infected Prunus avium, P. mume, and $P$. serrulata. The particles were observed in ultrathin sections of lower epidermis, palisade, and spongy mesophyll cells of leaves of P. avium and P. mume. Spring (March and April) appears to be optimal for detection of the particles in both screenhouse and field-grown plants. The particles were successfully graft-transmitted to $P$. armeniaca (cvs. Luizet and Tilton), P. avium (cvs. Bing, F12/1, Mazzard, and Sam), P. mahaleb, and P. persica (cv. Elberta). Individual spirions measured $132 \times 34 \mathrm{~nm}$. The particles appear to be coiled forms of a filamentous virus. Filaments extending from some coiled particles were approximately $13 \mathrm{~nm}$ wide, with striations at a pitch of $3.24 \mathrm{~nm}$. No disease symptoms or cytopathological abnormalities were associated with the presence of the particles in the Prunus species studied. The particles were not detected in virus-free control plants.
\end{abstract}

The etiologies of many economically important and quarantinable diseases that affect Prunus spp. are unknown (8). Indexing using woody indicators provides the only means of detection. This process is time-consuming and often unreliable, since symptom expression is affected by environmental conditions (10). Identification of the causal agent facilitates the development of more accurate and reliable techniques for detection. An unusual particle was observed in several species of Prunus. The particles were coiled or spiral in appearance, with a filamentous tail associated with some particles. They were similar in appearance to particles detected in species of Camellia with leaf yellow mottle disease $(1,2,6)$. Coiled structures were detected in ultrathin sections of pollen grains, in the mesophyll cells of young petals, and in the cytoplasm and nucleus of epidermal and mesophyll cells of Camellia leaves.

We report electron microscopic detection of similar particles in Prunus avium

Corresponding author: D. James

E-mail: jamesd@em.agr.ca

Accepted for publication 25 June 1999.

Publication no. D-1999-0823-01R

This article is in the public domain and not copyrightable. It may be freely reprinted with customary crediting of the source. The American Phytopathological Society, 1999. cv. Lambert, $P$. mume, and $P$. serrulata. Graft and mechanical transmission studies were carried out to identify any disease syndrome correlated with the occurrence of these particles in species of Prunus and to determine their infectious nature.

\section{MATERIALS AND METHODS}

Source of particles. Coiled particles were detected in the following species of Prunus: (i) P. avium cv. Lambert (isolate 2734B) known to be infected with cherry raspleaf and prune dwarf viruses originating from Oregon, graft-transmitted and maintained in P. avium cvs. Bing and Sam at the Pacific Agri-Food Research Centre, Summerland, B.C.; (ii) P. mume cv. Bungo (isolate 1256-01) infected with Prunus virus $(4,5)$ and imported from Japan in 1985; (iii) P. serrulata cv. Kiku Shidare Zakura (isolate 1044-01) infected with little cherry virus and imported from Holland in 1980; and (iv) P. serrulata cv. Kiku Shidare Zakura (340-02P2) infected with green ring mottle and little cherry viruses, originating in British Columbia, Canada. The disease status of the plants was determined by indexing on woody indicators, electron microscopy, and/or by serology.

Electron microscopy. Flower buds, leaf tissue, or root tissue from $P$. avium cvs. F12/1 and Lambert, $P$. serrulata, $P$. mahaleb, and healthy control plants were ground in $0.03 \mathrm{M}$ potassium phosphate buffer, $\mathrm{pH} 7.0$, containing $5 \mathrm{mM} \mathrm{MgCl}_{2}$ and $0.02 \% \mathrm{NaN}_{3}$. Formvar-carbon coated copper grids were floated on $10-\mu 1$ drops of the prepared extract for $30 \mathrm{~min}$. The grids were rinsed with 2 drops of filter-sterile double distilled water and stained with $2 \%$ aqueous uranyl acetate. The grids were examined, and particles were photographed using a JEOL JEM-100 or a Hitachi H7100 electron microscope calibrated with a grating replica (JBS 401:J.B.EM Services Inc., St. Laurent, Quebec). Mean lengths and widths of the particles were determined using a procedure similar to that described by Monette and James (7). Between 12 and 26 particles were measured to obtain the average size. A 12-month study using leaf dip assays was conducted to determine seasonal changes in distribution and concentration of the particles. Healthy control plants were included in all studies, and their disease status was also determined by indexing on woody indicators, electron microscopy, and/or serology.

Leaf and petal samples from infected $P$. avium cv. Lambert, $P$. mume, and from healthy control plants were fixed in a mixture of $2.5 \%$ glutaraldehyde and $1 \%$ paraformaldehyde in $0.1 \mathrm{M}$ sodium cacodylate buffer containing $4.5 \mathrm{mM}$ calcium chloride, $\mathrm{pH} 7.4$. The specimens were postfixed in $1 \%$ osmium tetroxide, dehydrated in a graded acetone series, and embedded in Spurr's resin (9). Ultrathin sections were prepared and mounted on Formvar-carbon coated copper grids and stained by immersion in $25 \%$ uranyl acetate (in methanol), followed by $0.1 \%$ basic lead citrate.

Immunosorbent electron microscopy (ISEM). ISEM was carried out as described by Van Regenmortel (11). After attempts at trapping and decorating the particles, the samples were stained with 2\% uranyl acetate. Polyclonal antisera tested included apple chlorotic leaf spot virus (ACLSV), apple stem grooving virus (ASGV), apple stem pitting virus (ASPV), cherry mottle leaf virus (CMLV), and plum pox virus (PPV, American Type Culture Collection PVAS-709). Plants infected with the appropriate viruses were used as positive controls.

Graft transmission studies. Two buds from $P$. avium cv. Lambert (origin Oregon) were T-budded onto each of three virusfree $P$. avium cv. Sam in December. The plants were maintained for 8 months in 1gallon pots in a greenhouse under ambient 
light and at a minimum temperature of $18^{\circ} \mathrm{C}$, then transferred to a secure screenhouse. After approximately 2 years, buds from each of these trees were grafted to three healthy Sam and Bing trees. Buds from infected $P$. mume were T-budded onto virus-free plants of $P$. armeniaca cvs. Tilton and Luizet, $P$. avium cvs. Mazzard and F12/1, P. mahaleb, and $P$. persica cv. Elberta. Two trees (2 years old) of each Prunus cultivar were inoculated, and two inoculum buds were placed on each tree. Buds from a $P$. mume plant free of the coiled viruslike particles were used to inoculate two trees of each Prunus cultivar as negative controls. Also, a collection of healthy Sam, Bing, and Lambert cherry trees, Tilton apricot trees, and Elberta peach trees was examined for comparison. The trees were grafted in the field in March and moved after 1 year to a greenhouse maintained at $20^{\circ} \mathrm{C}$ day and $18^{\circ} \mathrm{C}$ night, and illuminated for $16 \mathrm{~h}$ each day. Supplementary lighting was provided by high-pressure sodium lamps. The plants were allowed to undergo seasonal dormancy and were observed over a 3-year period for the development of symptoms.

Mechanical sap transmission. Attempts were made to transmit the coiled particles from their woody hosts to herbaceous species during March and April. Various tissue types were assessed to determine the effect of sap transmission, including bud scales, young leaves, mature leaves, immature flowers, petals, roots, and bark tissue. Inoculum was prepared by grinding $0.5 \mathrm{~g}$ of tissue in $5 \mathrm{ml}$ of one of the following buffers: (i) $0.01 \mathrm{M}$ phosphate buffer, $\mathrm{pH} 7.0$, containing $2.5 \%$ nicotine; (ii) $0.01 \mathrm{M}$ phosphate buffer, $\mathrm{pH} 7.0$, containing $0.02 \mathrm{M}$ diethyldithiocarbamic acid, sodium salt (DIECA), $0.04 \mathrm{M}$ sodium thioglycolate (ST), and $2.5 \%$ nicotine with a final $\mathrm{pH}$ 9.5; (iii) $0.05 \mathrm{M}$ phosphate buffer, $\mathrm{pH} 7.5$, containing $2 \%$ polyvinylpyrrolidone; (iv) $0.03 \mathrm{M}$ potassium phosphate buffer, $\mathrm{pH} 7.0$, containing $5.0 \mathrm{mM}$ magnesium chloride and $0.02 \mathrm{M}$ sodium azide; (v) $0.05 \mathrm{M}$ Tris, $\mathrm{pH} 8.5$, containing $0.01 \mathrm{M}$ magnesium sulfate, $0.02 \mathrm{M}$ DIECA, $0.04 \mathrm{M} \mathrm{ST}$, and $2.5 \%$ nicotine; (vi) $0.02 \mathrm{M}$ dipotassium hydrogen orthophosphate containing $0.5 \%$ bentonite, final $\mathrm{pH}$ 9.8; and (vii) $0.2 \mathrm{M}$ potassium phosphate buffer, $\mathrm{pH} 7.3$, containing 3\% activated charcoal and $16 \%$ celite. The herbaceous species (three plants each) inoculated were: Chenopodium quinoa, $C$. amaranticolor, Cucumis sativus, Nicotiana benthamiana, $N$. clevelandii, $N$. glutinosa, $N$. megalosiphon, $N$. occidentalis cv. 37B, and Physalis floridana. Plants were placed in the dark for $24 \mathrm{~h}$ prior to inoculation. Leaves were dusted with corundum (grit 600), except when buffer (vii) containing celite was used, and gently rub-inoculated. Inoculated plants were kept in a greenhouse maintained at light and temperature conditions previously described.

\section{RESULTS}

Electron microscopy. Coiled viruslike particles were detected in leaf-dip preparations of infected $P$. avium, $P$. mume, and $P$. serrulata (Fig. 1), but not in any of the healthy controls. Particles were found in samples of buds, young leaves, flowers, and root tissue. The predominant particles had an average size of $132 \mathrm{~nm}$ long and $34.4 \mathrm{~nm}$ wide, with an average of 12 coils or loops. There were no detectable differences in the sizes of particles from different sources. Occasionally, a group of particles appeared to be linked end-to-end by filamentous extensions (Fig. 1C and D). A few coiled particles with an average length of $268.9 \mathrm{~nm}$ and with twice the number of loops were also observed (Fig. 1B). These may represent end-to-end aggregates of the basic units. These aggregates rarely had filamentous extensions. Shorter particles $(<132 \mathrm{~nm})$ were always associated with flexuous filaments at one or both ends (Fig. 2A to F), indicating various degrees of uncoiling. Filaments extending from the partially uncoiled spirions were $13 \mathrm{~nm}$ wide, with striations of approximately 3.24 $\mathrm{nm}$ in pitch. Similar striations were observed on the fully uncoiled particles (Fig. 2B).

Coiled viruslike particles were also detected by electron microscopic examination of ultrathin sections of the leaves of $P$. avium cv. Bing and $P$. mume. Particles were detected in the cytoplasm of lower epidermis, palisade, and spongy mesophyl cells (Fig. 3). They were usually aligned in lateral aggregations, which often formed extended rows (Fig. 3A and C). The rows occurred singly or in stacks that resembled banded aggregates. The particles of some stacked rows appeared to be connected by their filaments (Fig. 3A). Transversely sectioned particles appeared as hollow tubes (Fig. 3B). Uncoiled particles were observed as disorganized aggregates of filamentous particles. Fibrous bundles were seen in both $P$. avium and $P$. mume (Fig. 3D). These bundles may represent another form of the particles or associated inclusion bodies. No unique virus-specific cellular abnormalities, other than the aggregates of particles and fibrous bundles, were found.

The coiled virus particles were most abundant during spring (March and April) and were rare in the summer and fall months (June through October), with a corresponding increase in the number of associated filamentous particles observed. During the months of November to Janu-

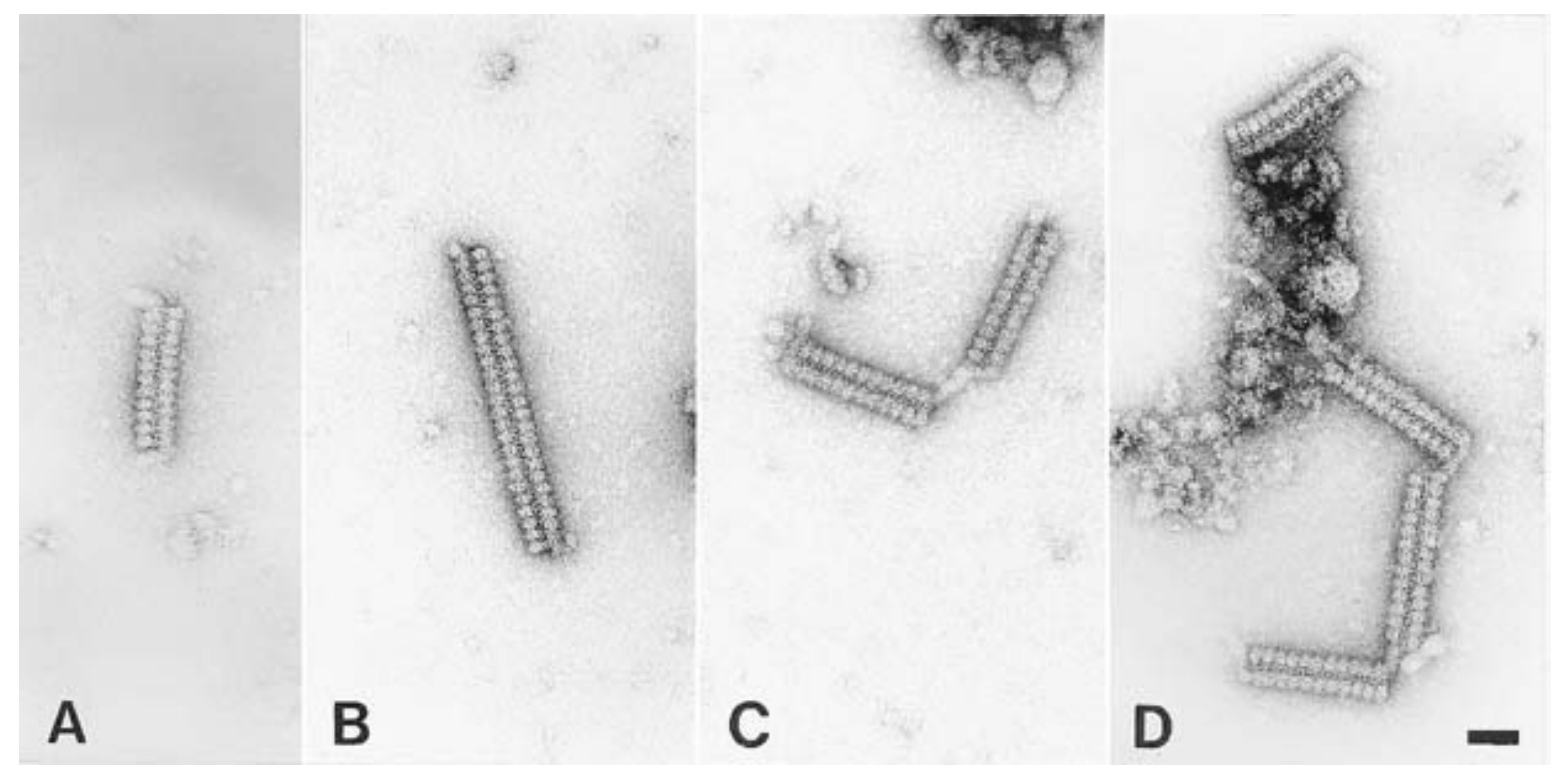

Fig. 1. Leaf-dip preparation of spirions (coiled viruslike particles) from crude extracts of immature leaves or flower petals. (A, B, and D) Isolate 1256-01 from a leaf of Prunus avium cv. F12/1. (C) Isolate 2734B from the flower petals of P. avium cv. Lambert. Stained with 2\% aqueous uranyl acetate. Bar = $42 \mathrm{~nm}$. 
ary, only filamentous particles were observed. This pattern was observed in both leaf-dip preparations and thin section examination.

Serology. Neither the coiled particles nor associated filaments reacted with any of the antisera included in the ISEM analyses. Trapping and decoration of the positive controls, but not of the coiled particles with associated filaments, were observed. Therefore, the coiled particles do not appear to be serologically related to ACLSV, ASGV, ASPV, CMLV, or PPV.

Graft and mechanical transmission tests. Coiled particles from the Oregon Lambert tree were detected after grafttransmission through two successive passages on $P$. avium cv. Sam. The Lambert tree showed no obvious disease symptoms, and subsequent transmission of the particles to Sam cherry did not result in little cherry disease symptoms. Particles were also successfully transmitted by budding from $P$. avium cv. Sam to $P$. avium cv. Bing. The $P$. mume-associated particles were transmitted to $P$. armeniaca cvs. Luizet and Tilton, $P$. avium cvs. Mazzard and $\mathrm{F} 12 / 1, P$. mahaleb, and $P$. persica cv. Elberta. Transmission was confirmed by electron microscope analysis of leaf-dip preparations, in that the particles were detected 12 to 14 months after budding. The coiled viruslike particles were not detected in any of the negative control plants. After observation for more than two seasons, no symptoms were detected in $P$. avium, $P$. armeniaca cv. Luizet, $P . \quad m a-$ haleb, or $P$. persica cv. Elberta infected with the particles. In the case of $P$. armeniaca cv. Tilton, chlorotic flecking and a mosaic pattern were observed on some early leaves, but no symptoms were seen on later developing leaves. Attempts at mechanical sap transmission of the coiled particles from species of Prunus to herbaceous hosts were unsuccessful.

\section{DISCUSSION}

Inouye and Inouye (3), Hiruki (2), Milicic et al. (6), and Gailhofer et al. (1) described the detection of coiled particles in species of Camellia, a valuable ornamental plant. The particles were associated with Camellia leaf yellow mottle disease and

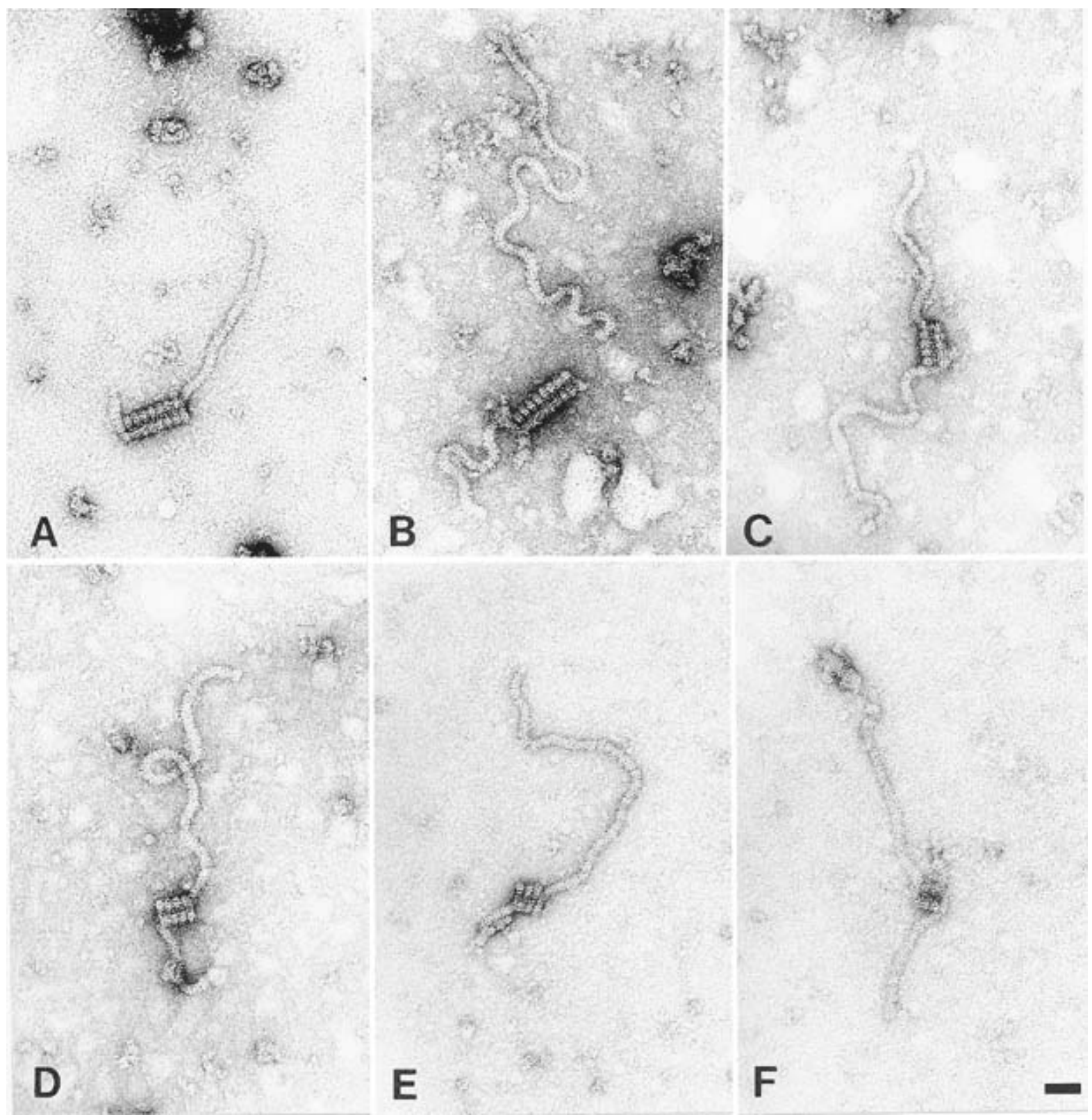

Fig. 2. Micrographs showing partially uncoiled particles. Particles from crude extracts are nonspecifically adsorbed to grids treated with various antisera. (A) Isolate 1044-01 from immature leaves of Prunus serrulata cv. Kiku Shidare Zakura treated with Prunus necrotic ringspot virus (PNRSV) antiserum. (B to D) Isolate 2734B from flower petals of $P$. avium cv. Lambert treated with plum pox virus (PPV) antiserum and showing particles with 8,5 , and 4 coils, respectively. (E) Isolate 1044-01 from flower petals of $P$. serrulata treated with PPV antiserum and showing particle with 3 coils. (F) Isolate 1256-01 from mature leaf of $P$. mahaleb treated with PPV antiserum and showing particle with 2 coils. Stained with $2 \%$ aqueous uranyl acetate. Bar $=42 \mathrm{~nm}$. 
were estimated to be 140 to $150 \times 25$ to 30 $\mathrm{nm}$. This is similar to the size of the coiled viruslike particles we detected in species of Prunus. Hiruki (2) also was not able to sap transmit the particles detected in Camellia. Either these particles are not mechanically transmissible or the right conditions for transmission have not been identified.

These particles, because of their morphology, are not prune dwarf or cherry raspleaf virus. The infected Oregon Lambert tree showed no symptoms of little cherry disease, and subsequent transmission to and indexing on Sam failed to yield little cherry disease symptoms. Moreover, past attempts to transmit the agent of little cherry to apricot and peach have been unsuccessful (12), whereas the coiled structures were successfully transmitted to both apricot and peach trees by grafting. This suggests that they are not the cause of little cherry disease. Particles were detected in two accessions of $P$. serrulata from different sources. One accession (1044-01) was indexed on Kwanzan cherry and shown to be negative for green ring mottle. It is therefore unlikely that the coiled particles are associated with green ring mottle disease.

Symptoms of chlorotic flecking and a mosaic pattern were observed on some

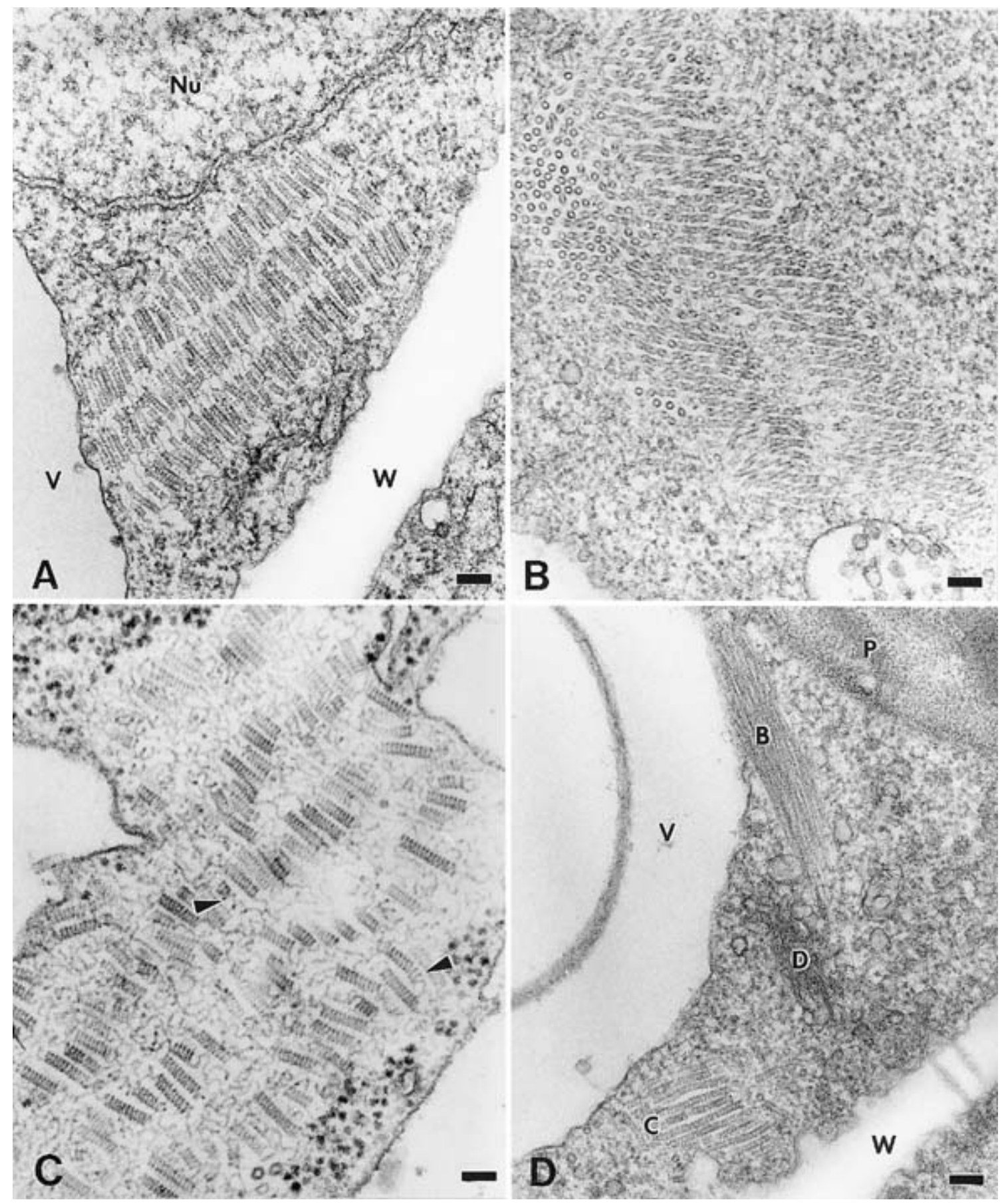

Fig. 3. Electron micrographs of ultrathin sections of immature leaves showing coiled particles in situ. (A) A three-layered aggregate of coiled particles in the cytoplasm of a spongy mesophyll cell of Prunus mume cv. Bungo. Filaments appear to be continuous from the coiled particles in one layer to those in the next layer. $\mathrm{Nu}=$ nucleus, $\mathrm{V}=$ vacuole, $\mathrm{W}=$ wall. $(\mathrm{Bar}=112 \mathrm{~nm})(\mathbf{B})$ Transverse and oblique sections of isolate 1256-01 coils in the parietal cytoplasm of a spongy mesophyll cell. A small vacuole containing vesicles is at lower right. $(B a r=107 \mathrm{~nm})(\mathbf{C})$ Portion of a 4-layered aggregate of coiled particles in a mesophyll cell of $P$. avium cv. Lambert. The coils are of various lengths and appear to be uncoiling to form a mass of twisted filamentous particles (arrows). (Bar $=66 \mathrm{~nm})(\mathrm{D})$ Palisade cell of $P$. mume containing an aggregate of long coils $(\mathrm{C})$ with a fibrous bundle (B) that may represent an aggregate of uncoiled particles. $\mathrm{D}=$ dictyosome, $\mathrm{P}=$ plastid, $\mathrm{V}=$ vacuole, $\mathrm{W}=$ cell wall. $(\mathrm{Bar}=115 \mathrm{~nm})$ All sections were stained with $25 \%$ uranyl acetate and $0.1 \%$ basic lead citrate. 
young leaves of $P$. armeniaca cv. Tilton infected with the coiled particles from $P$. mume. Another flexuous virus (PVI 125601) that reacted positively with plum pox virus and apple stem pitting virus antisera $(4,5)$ was cotransmitted to these Tilton apricot plants, so either one of these agents or the combination of agents may have been responsible for the symptoms. These symptoms have not been observed again.

The relationship between the coiled particles in Prunus and those in Camellia is undetermined, and the particles have not yet been associated with any specific symptoms in Prunus. If these particles are related, however, Prunus may act as a latent host for particles associated with disease in Camellia. Studies are under way to isolate and further characterize the particles in Prunus. Particle purification and production of antibodies will facilitate determination of the relationship between the coiled particles and the associated filamentous particles, and also between the putative Camellia leaf yellow mottle virus and the particles detected in Prunus. This is important since any attempt at disease control must take into account the host range of the associated pathogen. We suggest that the coiled particles be identified as spirions (spiral viruslike particles).

\section{ACKNOWLEDGMENTS}

We thank the East Malling Research Station for providing apple chlorotic leaf spot and apple stem grooving virus antisera, and we thank $\mathrm{H}$. Yanase for providing apple stem pitting virus antiserum.

\section{LITERATURE CITED}

1. Gailhofer, M., Thaler, I., and Milicic, D. 1988. Occurrence of Camellia leaf yellow mottle virus (CLYMV) on East Adriatic coast. Acta Hortic. 234:385-391.

2. Hiruki, C. 1985. A preliminary study on infectious variegation of Camellia. Acta Hortic. 164:55-62.

3. Inouye, T., and Inouye, N. 1975. Rod-shaped particles found in Camellia leaves with necrotic ring spots. (In Japanese) (Abstr.) Ann. Phytopathol. Soc. Jpn. 40:133.

4. James, D., Godkin, S. E., Eastwell, K. C., and MacKenzie, D. J. 1996. Identification and differentiation of Prunus virus isolates that cross-react with plum pox virus and apple stem pitting antisera. Plant Dis. 80:536-543.

5. James, D., Thompson, D. A., and Godkin, S.
E. 1994. Cross reactions of an antiserum to plum pox virus. EPPO Bull. 24:605-614.

6. Milicic, D., Thaler, I., and Gailhofer, M 1986. Infectious variegation virus of Camellia japonica L. in Yugoslavia. Acta Bot. Croat. 45:1-6.

7. Monette, P. L., and James, D. 1990. Detection of two strains of grapevine virus A. Plant Dis. 74:898-900.

8. Nemeth, M. 1986. Virus, Mycoplasma and Rickettsia Diseases of Fruit Trees. Akademiai Kiado, Budapest. Martinus-Nijhoff Publ., Boston.

9. Spurr, A. R. 1969. A low viscosity epoxy resin embedding medium for electron microscopy. J. Ultrastr. Res. 26:31-43.

10. Stouffer, R. F., and Fridlund, P. R. 1989. Indexing using woody indicators. Pages 255265 in: Viruses and Viruslike Diseases of Pome Fruits and Simulating Noninfectious Disorders. P. R. Fridlund, ed. Wash. State Univ. Coop. Ext. Serve., Pullman, SP 0003.

11. Van Regenmortel, M. H. V. 1982. Serology and Immunochemistry of Plant Viruses. Academic Press, New York.

12. Welsh, M. F., and Cheney, P. W. 1976. Little cherry. Pages 231-237 in: Virus Diseases and Noninfectious Disorders of Stone Fruits in North America. R. M. Gilmer, J. D. Moore, G. Nyland, M. F. Welsh, and T. S. Pine, eds. U.S Dep. Agric., Agric. Handb. 437 